\title{
POTENSI WILAYAH KECAMATAN CIKAKAK DALAM KERANGKA PENGEMBANGAN EKOWISATA PANTAI PALABUAN RATU KABUPATEN SUKABUMI
}

\author{
Oleh : Asep Mulyadi *)
}

\begin{abstract}
Abstrak
Ecotourism adalah perjalanan yang bertanggung jawab ketempat-tempat yang alami dengan menjaga kelestarian lingkungan dan meningkatkan kesejahtraan penduduk setempat". Ekoturisme sarat oleh aspek primer yakni, mengelaborasi alam untuk kepentingan pariwisata tanpa menurunkan kualitas alam, atau mengubahnya menjadi wujud intervensi penyebab degradasi ekosistem.

Kecamatan Cikakak adalah salah satu wilayah yang berada di kawasan pantai Palabuan Ratu Kabupaten Sukabumi. Wilayah ini memiliki potensi yang baik untuk menopang pengembangan kawasan wisata pantai Palabuan Ratu terutama pegembangan kearah ekowisata. Pengembangan kawasan ekowisata di Palabuan Ratu diyakini dapat meningkatkan perkembangan kawasan wisata di daerah ini yang bermanfaat tidak hanya bagi lingkungan fisik, tetapi juga masyarakat secara lebih luas dan berkelanjutan.

Potensi yang dimiliki oleh wilayah kecamatan Cikakak dalam pengembangan kawasan ke arah ekowisata meliputi potensi berbasis marine, berbasis agro, dan berbasis petualangan yang cukup memadai untuk dikembangkan. Melalui upaya-upaya dengan mempergunakan pendekatan yang komprehensif, kendala-kendala yang ada diyakini akan dapat di atasi.
\end{abstract}

Kata Kunci : Ecotourism, Kawasan Pantai, Pembangunan berbasis masyarakat.

*) Drs. Asep Mulyadi, M.Pd., adalah dosen Jurusan Pendidikan Geografi FPIPS UPI.

\section{Pendahuluan}

Kabupaten Sukabumi adalah salah satu dari 23 wilayah kabupaten dan kota di propinsi Jawa Barat yang memiliki potensi pariwisata yang sangat baik. Sektor pariwisata menjadi salah satu andalan dalam pembangunan di kabupaten Sukabumi. Kepariwisataan dipandang sebagai tolok ukur pertumbuhan yang sangat kuat dan memberikan dampak terhadap perkembangan ekonomi baik dari pendapatan sector formal maupun informal, yang berbasis ekonomi kerakyatan.

Hasil survey analisis pasar wisata Jawa Barat tahun 2006, menunjukkan bahwa sebagian besar responden $(82,2 \%)$ rekreasi dengan tujuan kabupaten Sukabumi adalah untuk menikmati rekreasi pantai sepanjang Palabuan Ratu hingga Cibangban. Hanya sebagian kecil $\quad(17,8 \%)$ memilih mengunjungi pegunungan (g. 
Salak atau gunung Gede). Hal tersebut menunjukkan daya tarik obyek wisata pantai lebih utama (Bappeda Pemkab. Sukabumi, 2007).

Untuk menjaga kesinambungan dan meningkatkan arus kunjungan wisata ke kawasan pantai di kabupaten Sukabumi khususnya kawasan pantai Palabuan Ratu hingga Cisolok, perlu upaya pengembangan daya tarik obyek atau destinasi wisata baik secara kuantitas maupun kualitas di kawasan tersebut. Hal tersebut diharapkan disamping dapat meningkatkan pemenuhan kebutuhan wisata pengunjung, juga dapat berdampak memperluas kesempatan pencaharian atau pendapatan masyarakat setempat. Tidak jarang pengembangan daerah wisata di suatu tempat berakibat penurunan kualitas atau nilai daya tarik obyek atau kawasan wisata tersebut, karena tidak memeperhatikan aspek-aspek lainnya yang penting, seperti tidak diciptakan dan digalinya destinasi, obyek-obyek atau atraksi-atraksi wisata baru yang sesungguhnya dimiliki oleh kawasan tersebut, sehingga pengunjung memiliki pilihan untuk melengkapi pilihan yang ada. Tidak jarang pula aktivitas wisata tidak berdampak positif bahkan cenderung negative pada lingkungan setempat, seperti pencemaran lingkungan, dan masalah-masalah social bagi penduduk setempat. Untuk itu diperlukan sebuah konsep pengembangan obyek atau daerah pariwisata yang tidak hanya dapat memenuhi kebutuhan seorang wisatawan, tetapi juga aktivitas pariwisata dapat memenuhi kebutuhan kehidupan masyarakat pada umumnya maupun masyarak setempat secara berkelanjutan. Salah satu konsep pengembangan wisata berkelanjutan adalah ekowisata (ecotourism).

Ekowisata (Ecotourism) pada dasarnya adalah bentuk wisata yang terkait dengan konsep pelestarian lingkungan dan pemberdayaan penduduk lokal. Ekowisata berkembang dari adanya suatu perpaduan antara minat yang tumbuh dari keprihatinan terhadap lingkungan, ekonomi dan sosial. Ekowisata tidak dapat dipisahkan dengan konservasi. Oleh karenanya, ekowisata disebut sebagai bentuk perjalanan wisata bertanggungjawab.

Perkembangan dari aktivitas pariwisata saat ini, di sepanjang kawasan pantai Pelabuan Ratu sampai Cisolok di sebelah baratnya hanya didominasi oleh usaha akomodasi dan rumah makan, nampak sekali belum ada usaha pariwisata representatif dan memadai. Obyek Daya Tarik Wisata (ODTW) di kabupaten Sukabumi sesungguhnya pada umumnya cukup beragam seperti pantai, panorama, peninggalan sejarah, pegunungan, seni budaya dan lain-lain yang sering disebut dengan ungkapan "gurilap" (gunung, rimba, laut, panorama dan pantai). Hanya saja ODTW tersebut pertumbuhannya belum seimbang. Atas dasar pemikiran tersebut maka penting untuk diadakan berbagai kajian dan penelitian khususnya pada kawasan pantai Palabuan Ratu, sehingga diperoleh masukan-masukan yang dapat megembangkan kawasan ini sebagai kawasan wisata terpadu yang dapat memberikan peningkatan kesejahteraan bagi masyarakat seluas-luasnya.

Mengingat luasnya wilayah kawasan pantai Pelabuan Ratu, maka penulis membatasi untuk memeperoleh gambaran potensi pada salah satu kecamatan di kawasan ini yaitu wilayah Kecamatan Cikakak ditinjau dari sudut potensi pengembagan ekowisatanya. 


\section{a. Rumusan Masalah}

Berdasarkan latar belakang masalah dan penjelasan yang telah diuraikan diatas, maka penulis merumuskan masalah yang akan diteliti sebagai berikut:

1) Bagaimana potensi fisik dan sosial yang mendukung pengembangan ecotourism di Kecamatan Cikakak ?

2) Apa kendala yang dihadapi dalam pengembangan ecotourism di Kecamatan Cikakak?

3) Bagaimana upaya pengembangan ecotourism di kecamatan Cikakak sebagai bagian dari pengembangan kawasan ekowisata di teluk Palabuanratu ?

\section{b. Tujuan Penelitian}

Tujuan yang ingin dicapai dari penelitian ini adalah :

1) Mengidentifikasi potensi fisik dan sosial yang mendukung pengembangan ecotourism di Kecamatan Cikakak.

2) Mengidentifikasi kendala yang dihadapi dalam pengembangan ecotourism di kecamatan Cikakak.

3) Menganalisis upaya yang dapat dikembangkan kearah pengembangan ecotourism di Kecamatan Cikakak untuk menjadi bagian dari kawasan pengembangan Ekowisata Teluk Palabuanratu

\section{c. Metode Penelitian}

Lokasi penelitian dilakukan di wilayah kecamatan Cikakak. Metode yang digunakan dalam penelitian ini adalah deskriptif, yakni menggambarkan keadaan daerah penelitian, mengungkap fakta-fakta yang ada, melalui interpretasi dan analisis hasil penelitian yang ditarik dari permasalahan yang ada pada masa sekarang. Pengumpulan data dilakukan melalui observasi/pengamatan, wawancara, studi pustaka dan studi dokumentasi. Observasi dilakukan pada obyek terutama lingkungan fisikal dan lahan untuk mendapatkan gambaran yang aktual, dengan melakukan pengamatan dan pengukuran data secara langsung di lapangan yang berkaitan dengan pengembangan ecotourism. Wawancara dilakukan kepada masyarakat setempat maupun pengunjung. Wawancara dilakukan untuk mendapatkan data sosial yang ada di daerah penelitian sehingga dapat diketahui bagaimana kondisi social masyarakat yang dapat mendukung pengembangan ecotourism di wilayah ini.

\section{Tinjauan Pustaka}

a. Pengertian Ekowisata ( Ecotourism)

Menurut The International Ecotourism Society atau TIES (1991), ecotourism adalah perjalanan wisata ke wilayah-wilayah alami dalam rangka mengkonservasi atau menyelamatkan lingkungan dan memberi penghidupan penduduk lokal. Menurut World Conservation Union (WCU), ecotourism adalah perjalanan wisata ke wilayah-wilayah yang lingkungan alamnya masih asli, dengan menghargai warisan budaya dan alamnya, mendukung upaya-upaya konservasi, 
tidak menghasilkan dampak negatif, dan memberikan keuntungan sosial ekonomi serta menghargai partisipasi penduduk lokal.

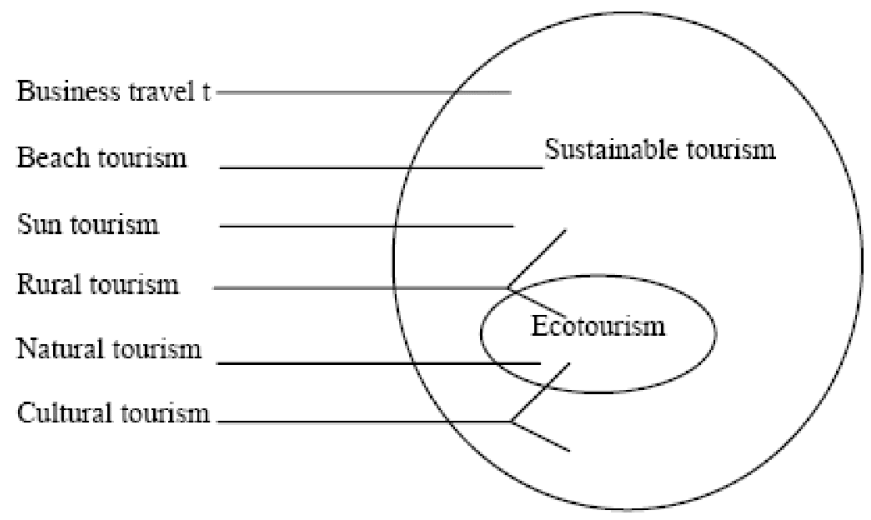

Gambar 1: Sustainable tourism and ecotourism (Wood, 2002)

Ecotourism adalah sebagian dari sustainable tourism. Sustainable tourism sector ekonomi yang lebih luas dari Ecotourism yang mencakup sektor-sektor pendukung kegiatan tourism secara umum (Gambar 1.1). Menurut deklarasi Quebec (hasil pertemuan dari anggota TIES di Quebec, Canada tahun 2002), Ecotourism adalah sustainable tourism yang secara spesifik memuat upaya-upaya:

1) Konstribusi aktif dalam konservasi alam dan budaya

2) Partisipasi penduduk lokal dalam perencanaan, pembangunan dan operasional kegiatan wisata serta meninkamti kesejahteraan.

3) Transfer pengetahuan tentang warisan budaya dan alam kepada pengunjung Sustainable tourism

4) Bentuk wisata independen atau kelompok wisata berukuran kecil

Sementara itu WCD (2000) menyatakan bahwa Ecotourism adalah sustainable tourism yang :

1) Menjamin partisipasi yang setara, efektif dan aktif dari seluruh stakeholder

2) Menjamin partisipasi penduduk lokal menyatakan yess atau no dalam kegiatan pengembangan masyarakat, lahan dan wilayah

3) Mengangkat mekanisme penduduk lokal dalam hal kontrol dan pemeliharaan sumberdaya.

Sementara itu Wood (2002) mendefinisikan ecotourism sebagai bentuk usaha atau sektor ekonomi wisata alam yang dirumuskan sebagai bagian dari pembangunan berkelanjutan. Berdasarkan definisi, konsep atau pengertian di atas, maka dapat disusun difinisi baru sebagai berikut:

Ecotourism adalah kegiatan perjalanan wisata yang dikemas secara profesional, terlatih, dan memuat unsur pendidikan, sebagai suatu sektor/usaha ekonomi, yang mempertimbangkan warisan budaya, partisipasi dan kesejahteraan penduduk lokal serta upaya-upaya konservasi sumberdaya alam dan lingkungan

Sebagai suatu sektor usaha, efektifitas operasional jasa ecotourism biasanya sangat efisien dan ramping. Perjalanan wisata terdiri dari kelompok-kelompok kecil 
berukuran kurang dari 25 orang. Hal ini akan mencegah dampak sosial dan lingkungan yang bersifat masif akibat kehadiran fisik pengunjung. Akomodasi penginapan memuat kurang dari 100 tempat tidur sehingga mencerminkan beroperasinya usaha kecil dan menengah dan partisipasi penduduk lokal. Kegiatan wisata memberikan unsure pendidikan yang sistematis dalam rangka pemahaman lingkungan secara komprehensif. Oleh sebab itu, sektor usaha ecotourism memerlukan specialist guide yang trampil, pintar dan berdedikasi.

Rumusan 'ecotourism' sebenarnya sudah ada sejak 1987 yang dikemukakan oleh Hector Ceballos-Lascurain yaitu sbb:

"Nature or ecotourism can be defined as tourism that consist in travelling to relatively undisturbed or uncontaminated natural areas with the specific objectives of studying, admiring, and enjoying the scenery and its wild plantas and animals, as well as any existing cultural manifestations (both past and present) found in the areas."

"Wisata alam atau pariwisata ekologis adalah perjalanan ketempat-tempat alami yang relatif masih belum terganggu atau terkontaminasi (tercemari) dengan tujuan untuk mempelajari, mengagumi dan menikmati pemandangan, tumbuhtumbuhan dan satwa liar, serta bentuk-bentuk manifestasi budaya masyarakat yang ada, baik dari masa lampau maupun masa kini."

Kemudian disempurnakan oleh The International Ecotourism Society (TIES) pada awal tahun 1990 yaitu sebagai berikut:

"Ecotourism is responsible travel to natural areas which conserved the environment and improves the welfare of local people."

Ecotourism adalah perjalanan yang bertanggung jawab ketempat-tempat yang alami dengan menjaga kelestarian lingkungan dan meningkatkan kesejahtraan penduduk setempat".

Adanya unsur plus di atas yaitu kepedulian, tanggung jawab dan komitmen terhadap kelestarian lingkungan dan peningkatan kesejahtraan masyarakat setempat ditimbulkan oleh:

1) Kekuatiran akan makin rusaknya lingkungan oleh pembangunan yang bersifat eksploatatif terhadap sumber daya alam.

2) Asumsi bahwa pariwisata membutuhkan lingkungan yang baik dan sehat.

3) Kelestarian lingkungan tidak mungkin dijaga tanpa partisipasi aktif masyarakat setempat.

4) Partisipasi masyarakat lokal akan timbul jika mereka dapat memperoleh manfaat ekonomi ('economical benefit') dari lingkungan yang lestari.

5) Kehadiran wisatawan (khususnya ekowisatawan) ke tempat-tempat yang masih alami itu memberikan peluas bagi penduduk setempat untuk mendapatkan penghasilan alternatif dengan menjadi pemandu wisata, porter, membuka homestay, pondok ekowisata (ecolodge), warung dan usaha-usaha lain yang berkaitan dengan ekowisata, sehingga dapat meningkatkan kesejahtraan mereka atau meningkatkan kualitas hidpu penduduk lokal, baik secara materiil, spirituil, kulturil maupun intelektual. 
Suatu kegiatan pariwisata dapat dikategorikan pariwisata ekologi jika memenuhi 5 prinsip ekoturisme (Cooper;1997). Kelima prinsip tersebut,

1) Prinsip sustainable adalah pariwisata yang berkonsentrasi pada penyokongan pelestarian alam.

2) Bahwa lingkungan alam harus aman dan terjamin keselamatannya untuk dijadikan harta warisan bagi generasi mendatang.

3) Pemeliharaan beragam mahluk yang ada di sekitarnya, baik manusia, hewan, tumbuhan dan lain-lainnya apa pun yang berasal dari alam dan hidup di alam bersangkutan. Keragaman makhluk hidup diyakini dapat bertahan jika secara ekosistem terjaga.

4) Merumuskan perencanaan secara holistik dan mengimplementasikannya secara holistik pula. Harmonisasi alam dengan manusia dan totalitas lingkungannya (environmental integrity) harus jadi kenyataan.

5) Carying capacity, artinya seluruh pihak yang terlibat dalam kegiatan pariwisata tersebut mendapat manfaat. Tingkat kemanfaatan harus diperoleh baik secara dimensional bagi penyedia maupun bagi wisatawan.

b. Konsep Pengembangan Ekowisata

Untuk mengembangkan ekowisata dilaksanakan dengan cara pengembangan pariwisata pada umumnya. Ada dua aspek yang perlu dipikirkan. Pertama, aspek destinasi, kemudian kedua adalah aspek market. Untuk pengembangan ekowisata dilaksanakan dengan konsep product driven. Meskipun aspek market perlu dipertimbangkan namun macam, sifat dan perilaku obyek dan daya tarik wisata alam dan budaya diusahakan untuk menjaga kelestarian dan keberadaannya. Pada hakekatnya ekowisata yang melestarikan dan memanfaatkan alam dan budaya masyarakat, jauh lebih ketat dibanding dengan hanya keberlanjutan. Pembangunan ekowisata berwawasan lingkungan jauh lebih terjamin hasilnya dalam melestarikan alam dibanding dengan keberlanjutan pembangunan. Sebab ekowisata tidak melakukan eksploitasi alam, tetapi hanya menggunakan jasa alam dan masyarakat untuk memenuhi kebutuhan pengetahuan, fisik/ dan psikologis wisatawan. Bahkan dalam berbagai aspek ekowisata merupakan bentuk wisata yang mengarah ke metatourism. Ekowisata bukan menjual destinasi tetapi menjual filosofi. Dari aspek inilah ekowisata tidak akan mengenal kejenuhan pasar.

The Ecotourism Society (Eplerwood/1999) menyebutkan ada delapan prinsip pengembangan ekowisata, yaitu:

1) Mencegah dan menanggulangi dampak dari aktivitas wisatawan terhadap alam dan budaya, pencegahan dan penanggulangan disesuaikan dengan sifat dan karakter alam dan budaya setempat.

2) Pendidikan konservasi lingkungan. Mendidik wisatawan dan masyarakat setempat akan pentingnya arti konservasi. Proses pendidikan ini dapat dilakukan langsung di alam.

3) Pendapatan langsung untuk kawasan. Mengatur agar kawasan yang digunakan untuk ekowisata dan manajemen pengelola kawasan pelestarian dapat 
menerima langsung penghasilan atau pendapatan. Retribusi dan conservation tax dapat dipergunakan secara langsung untuk membina, melestarikan dan meningkatkan kualitas kawasan pelestarian alam.

4) Partisipasi masyarakat dalam perencanaan. Masyarakat diajak dalam merencanakan pengembangan ekowisata. Demikian pula di dalam pengawasan, peran masyarakat diharapkan ikut secara aktif.

5) Penghasilan masyarakat. Keuntungan secara nyata terhadap ekonomi masyarakat dari kegiatan ekowisata mendorong masyarakat menjaga kelestarian kawasan alam.

6) Menjaga keharmonisan dengan alam. Semua upaya pengembangan termasuk pengembangan fasilitas dan utilitas harus tetap menjaga keharmonisan dengan alam. Apabila ada upaya disharmonize dengan alam akan merusak produk wisata ekologis ini. Hindarkan sejauh mungkin penggunaan minyak, mengkonservasi flora dan fauna serta menjaga keaslian budaya masyarakat.

7) Daya dukung lingkungan. Pada umumnya lingkungan alam mempunyai daya dukung yang lebih rendah dengan daya dukung kawasan buatan. Meskipun mungkin permintaan sangat banyak, tetapi daya dukunglah yang membatasi.

8) Peluang penghasilan pada porsi yang besar terhadap negara. Apabila suatu kawasan pelestarian dikembangkan untuk ekowisata, maka devisa dan belanja wisatawan didorong sebesar-besarnya dinikmati oleh negara atau negara bagian atau pemerintah daerah setempat.

Dengan pengertian tersebut di atas maka dapat dijabarkan beberapa prinsip yang menjadi karakteristik khusus suatu kegiatan ecotourism yaitu:

1) Meningkatkan etika lingkungan dan perilaku yang positif dari pelakupelakunya. Artinya, penyelenggaraan perjalanan tersebut membuat wisatawan, industri pariwisata, pemerintah dan masyarakat setempat makin ramah lingkungan.

2) Tidak menurunkan kualitas sumber daya alam. Prinsip ini memiliki konsekuensi yang sangat panjang. Untuk menjaga kualitas lingkungan, pada tahap perencanaan harus dilakukan pengukuran daya dukung lingkungan, pada tahap pelaksanaan harus digunakan metoda dan teknik yang meminimasi dampak, sementara itu perlu dilakukan upaya monitoring yang berkesinambungan

3) Berkonsentrasi pada nilai-nilai intrinsik bukan pada nilai ekstrinsik. Artinya, daya tarik utama dari suatu tujuan ecotourism adalah apa yang terdapat di lingkungan itu sendiri (misal: keanekaragaman hayati, keaslian alam), bukannya fasilitas atau komponen lainnya (misal: akomodasi, restoran).

4) Berorientasi pada pertimbangan kepentingan/sekitar lingkungan, bukan sekitar manusia. Seiring dengan prinsip nomor tiga, sebuah penyelenggaraan ecotourism, tidak 'mengorbankan' lingkungan untuk kepentingan manusia. Oleh karena itu, pembangunan fasilitas yang dibutuhkan oleh pengunjung dibatasi dan jangan sampai mengganggu berlangsungnya proses alamiah penting. 
5) Harus bermanfaat bagi satwa liar dan lingkungannya. Pelaksanaan ecotourism, bukan sekedar 'tidak mengganggu' satwa liar dan lingkungannya, melainkan harus memberikan kontribusi bagi keberlanjutannya. Oleh karena itu, slogan "take only pictures and leave only footsteps" tidak lagi dapat menjadi prinsip ecotourism karena tidak memberikan kontribusi apa-apa pada lingkungan yang dikunjunginya dan 'penghuninya'.

6) Menyediakan pengalaman langsung dengan lingkungan alam (dan budaya yang ada disekitarnya) di daerah yang belum terbangun.

7) Secara aktif melibatkan masyarakat lokal dalam proses-proses kepariwisataan. Proses-proses kepariwisataan merupakan proses yang cukup panjang, meliputi perencanaan, pengambilan keputusan, persiapan, pelaksanaan, monitoring dan seterusnya, dan sebuah penyelenggaraan ecotourism melibatkan masyarakat setempat dalam seluruh rangkaian proses tersebut, bukan hanya pada satu proses saja.

8) Tingkat kepuasan wisatawan diukur dari kadar pendidikan dan penghargaannya terhadap lingkungan bukan dari pencapaian fisik dan penaklukan tantangan olehnya. Keberhasilan sebuah perjalanan ecotourism dinilai dari banyaknya pengetahuan, tingginya kesadaran dan, pada gilirannya menimbulkan tingginya penghargaan wisatawan terhadap lingkungan, bukannya pada jauhnya jarak yang berhasil ditempuh atau tingginya gunung yang berhasil didaki.

9) Melibatkan persiapan dan pengetahuan yang mendalam baik dari sisi pemandu/pemimpin wisata, wisatawan, maupun masyarakat setempat. Tanpa persiapan dan pengetahuan yang memadai mengenai alam dan budaya, yang akan dikunjungi maupun yang akan mengunjungi, akan sulit tercapai saling pengertian antar pihak yang terlibat.

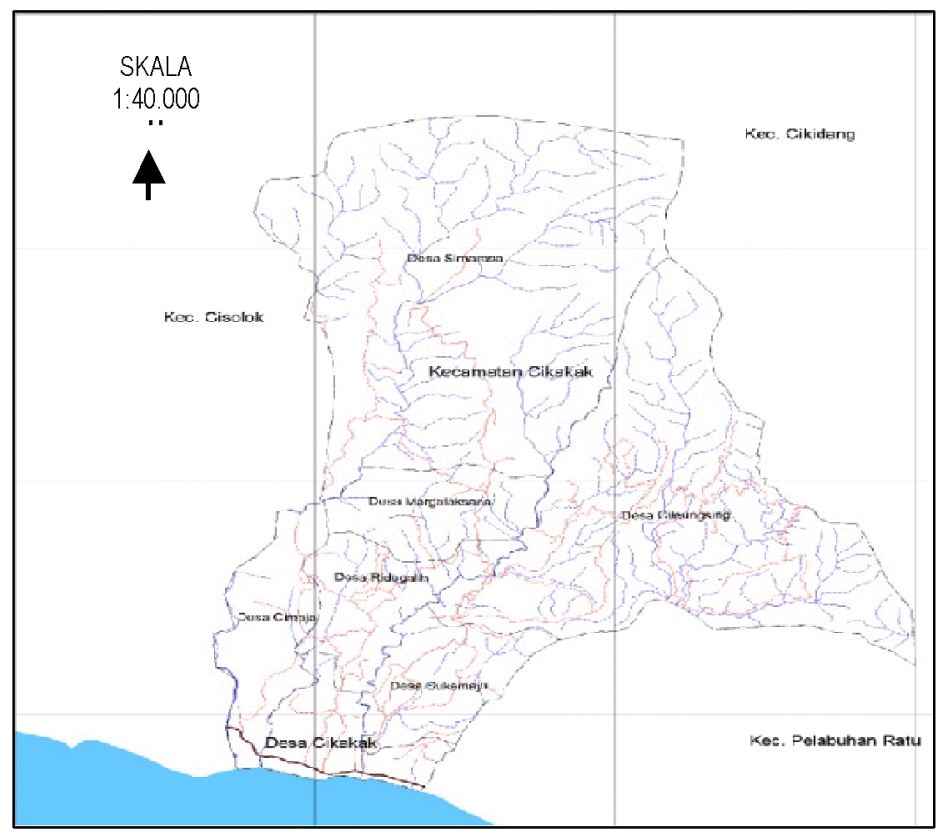

Gambar 2: Peta Administrasi Kecamatan Cikakak 


\section{Hasil Penelitian}

a. Potensi Ekowisata Lingkungan Fisik dan Sosial Kecamatan Cikakak

1) Titik Pengamatan 1: Pantai Sukawayana

- Ecoturism berbasis marine

\begin{tabular}{|c|c|}
\hline POTENSI PARIWISATA & \\
\hline Bentuk garis pantai $\quad$ : landai & Arah gelombang : utara (sejajar pantai) \\
\hline Tinggi gelombang & Periode gelomang $\quad: 14,7$ detik \\
\hline Bentuk breaker & Lebar garis pantai \\
\hline Bentuk pantai & Jenis pantai \\
\hline Jenis batuan pantai & Material batuan pantai : pasir \\
\hline $\begin{array}{l}\text { Warna air laut : keruh (biru } \\
\text { kehijauan bercampur pasir) }\end{array}$ & Terumbu karang $\quad$ : tidak ada \\
\hline Rumput laut $\quad$ : tidak ada & $\begin{array}{ll}\text { Jenis sampah } & \text { : organik, anorganik }\end{array}$ \\
\hline Kerapatan sampah $\quad$ : jarang & $\begin{array}{l}\text { Cara membersihkan sampah : oleh pemilik } \\
\text { warung dan petugas kehutanan }\end{array}$ \\
\hline $\begin{array}{l}\text { Wahana penangkapan ikan : bagan } \\
\text { terapung }\end{array}$ & Jenis ikan tangkapan : tongkol, imun \\
\hline Alat penangkap ikan $\quad$ : jaring & Musim banyak ikan $\quad$ : Juni \\
\hline $\begin{array}{l}\text { Musim jarang ikan } \quad \text { : arah angin dari } \\
\text { barat }\end{array}$ & $\begin{array}{l}\text { Cara menjual hasil tangkapan : TPI (Tempat } \\
\text { Pelelangan Ikan) }\end{array}$ \\
\hline DAYA TARIK WISATA & \\
\hline : voli pantai, berkuda, berj & mur, surfing dan wisata rohani \\
\hline : Jumat, Sabtu dan Mingg & atau weekend \\
\hline : semua umur dan wisatav & \\
\hline $\begin{array}{l}\text { Cara menyelenggarakannya : menyediakan } 1 \\
\text { barang seperti bola voli, payung, menyediak } \\
\text { surfing. }\end{array}$ & $\begin{array}{l}\text { pangan voli, menyediakan alat penyewaan } \\
\text { n bahan-bahan untuk berziarah, peralatan }\end{array}$ \\
\hline $\begin{array}{l}\text { Keterlibatan masyarakat : melalui penanama } \\
\text { para wisatawan dapat berteduh dibawah poh } \\
\text { warung untuk kebutuhan para wisatawan, da } \\
\text { setiap kegiatan. Serta dapat menikmati keinc } \\
\text { yang ada di pelabuhan ratu terutama cerita } n\end{array}$ & $\begin{array}{l}\text { pohon seperti waru dan ketapang sehingga } \\
\text { n, masyarakat dapat mendirikan warung- } \\
\text { ikut berpartisipasi dalam menyelenggarakan } \\
\text { han dengan mendengarkan sejarah-sejarah } \\
\text { ngenai Nyi Roro Kidul. }\end{array}$ \\
\hline $\begin{array}{l}\text { Analisis keberlanjutan : dengan dikembang } \\
\text { dibiasakan untuk menjaga lingkungannya ag } \\
\text { wisatawan tersebut tidak hanya melihat kein } \\
\text { menikmati liburannya dengan kesan yang m } \\
\text { wisatawan lebih banyak lagi }\end{array}$ & $\begin{array}{l}\text { Innya kegiatan tersebut masyarakat harus } \\
\text { r terasa nyaman dan bersih sehingga para } \\
\text { ahan tempat tersebut melainkan dapat } \\
\text { muaskan dan juga dapat menarik para }\end{array}$ \\
\hline Bentuk pengamanan wisata : penjaga panta & \\
\hline
\end{tabular}

- Ecoturism berbasis Agro

\begin{tabular}{|l|l|}
\hline Bentuk penggunaan lahan : hutan hujan tropis & Air yang digunakan : air tanah \\
\hline Kedalaman muka air tanah : $50 \mathrm{~m}$ & Rasa air tanah : tawar \\
\hline Warna air tanah : bening & Ketersediaan air : cukup \\
\hline $\begin{array}{l}\text { Jenis tanaman : waru, ketapang, dan vegetasi } \\
\text { hutan hujan tropis }\end{array}$ & Tinggi tanaman : $15-20 \mathrm{~m}$ \\
\hline Kerapatan/jarak tanaman : rapat & Umur tanaman : puluhan - ratusan tahun \\
\hline Kegunaan tanaman : konservasi & Cara menanam : alami, sengaja ditanam \\
\hline
\end{tabular}


Potensi yang bisa dilakukan di tempat penelitian kami, yaitu Cikakak adalah sebagai berikut :

Jenis

Waktu

Segmen pasar

outbond

Cara menyelenggarakannya weekend

Keterlibatan masyarakat anak-anak sampai dewasa

menyediakan sarana dan prasarana outbond.

menyediakan penyewaan peralatan untuk outbond. Serta masyarakat dapat bekerja di tempat kegiatan untuk menjaga kebersihan dan merawat tempat kegiatan.

Analisis keberlanjutan : ekologi di sekitar/lingkungan kegiatan harus dijaga karena dengan adanya ekologi yang masih asri maka para wisatawan dapat mengikuti setiap kegiatan dengan nyaman dan sejuk. Sedangkan kegiatan outbond membutuhkan pepohonan yang kuat.

Bentuk pengamanan wisata : pemandu setiap kegiatan.

2) Titik Pengamatan 2 :

- Ecoturism berbasis marine

\begin{tabular}{|l|l|}
\hline Bentuk garis pantai : landai & Arah gelombang : utara (sejajar pantai) \\
\hline Tinggi gelombang $: 1-1,5 \mathrm{~m}$ & Periode gelomang : 18,7 detik \\
\hline Bentuk breaker : buatan dan alami & Lebar garis pantai : $5,5 \mathrm{~m}$ \\
\hline Bentuk pantai : Cembung & Jenis pantai : teluk \\
\hline Jenis batuan pantai : gamping & Material batuan pantai : pasir \\
\hline $\begin{array}{l}\text { Warna air laut : keruh (biru kehijauan } \\
\text { bercampur pasir) }\end{array}$ & Terumbu karang : tidak ada \\
\hline Rumput laut : tidak ada & Jenis sampah : organik dan anorganik \\
\hline Kerapatan sampah : jarang & Cara membersihkan sampah : di bakar \\
\hline Wahana penangkapan ikan : Mancing & Jenis ikan tangkapan : tongkol, imun \\
\hline Alat penangkap ikan : Pancingan & Musim banyak ikan : - \\
\hline Musim jarang ikan : - & $\begin{array}{l}\text { Cara menjual hasil tangkapan : konsumsi } \\
\text { pribadi }\end{array}$ \\
\hline
\end{tabular}

- Ecoturism berbasis agro

\begin{tabular}{|l|l|}
\hline $\begin{array}{l}\text { Bentuk penggunaan lahan : Pemukiman, } \\
\text { Kebun Campuran dan tambak }\end{array}$ & Air yang digunakan : air tanah \\
\hline Kedalaman muka air tanah : $50 \mathrm{~m}$ & Rasa air tanah : tawar \\
\hline Warna air tanah : bening & Ketersediaan air : Banyak \\
\hline Jenis tanaman : pisang, dan kelapa & Tinggi tanaman : $10-15 \mathrm{~m}$ \\
\hline Kerapatan/jarak tanaman : cukup rapat & Umur tanaman : puluhan tahun \\
\hline Kegunaan tanaman : Produksi & $\begin{array}{l}\text { Cara menanam : alami dan sengaja } \\
\text { ditanam }\end{array}$ \\
\hline Fungsi tanaman pada : ekonomi & \\
\hline
\end{tabular}


3) Titik Pengamatan 3: Pantai Cempaka Ratu

- Ecotourism Berbasis Marine

Bentuk pantai di Cempaka Ratu bergelombang, arah gelombang ke utara, tinggi gelombang 1-1,5 meter, periode gelombang rata-rata 6 detik, lebar garis pantai 15 meter, bentuk pantai lurus, jenis pantai teluk, jenis batuan andesit, warna air laut jernih, salinitas air laut sedang, kerapatan sampah jarang, jenis sampah organik dan non organik, wahana penangkap akan perahu dan pagang, jenis ikan tangkapan tongkol, marlyn dan teri, alat penengkap ikan jaring, periode penangkapan ikan tidak tentu, musim banyak ikan pada saat pergantian musim (Januari, Februari, Maret, Agustus, September dan Oktober), cara menjual hasil tangkapan ke TPI.

- Ecotourism Berbasis Agro

Bentuk penggunaan lahan yaitu sawah, tegalan, kebun dan pemukiman. Air yang digunakan PAM dan sumur, Kedalaman muka air tanah 5-7 meter, rasa air tanah tawar, warna air tanah jernih, ketersediaan air cukup, jenis tanaman yang tumbuh padi dan cengkeh, tinggi tanaman padi (rata-rata kurang dari 1 meter tergantung jenis padi) tinggi tanaman cengkeh rata-rata 7-8 meter, kerapatan/ jarak tanaman padi rata-rata $30-50 \mathrm{~cm}$ dan cengkeh 4 meter. Umur tanaman padi kurang lebih 4 bulan, tanaman cengkeh rata-rata10-50 tahun. Produksi/ hasil tanaman padi adalah biji padi sedangkan cengkeh adalah buah cengkehnya. Kegunaan tanaman padi sebagai bahan pangan sedangkan cengkeh adalah untuk pembuatan minyak wangi/ atsiri. Cara memelihara tanaman padi dengan sistem pengairan yang tepat dan menggunakan pupuk organik sedangkan untuk tanaman cengkeh yaitu dengan cara membersihkan tanaman cengkeh dari tanaman liar atau semak-semak termasuk hama tanaman. Fungsi tanaman cengkeh selain diambil buahnya juga dapat menahan erosi tanah dan juga untuk keteduhan.

- Ecotourism Berbasis Petualangan

Bentuk lahan berbukit, bentuk lereng agak curam, kemiringan lereng $20^{\circ}-$ $30^{\circ}$, jenis batuan breksi dan andesit, jenis sesar adalah patahan.

\section{4) Titik Pengamatan 4 :}

- Zona Budidaya Dengan Potensi Children Playground

Sekitar 30 meter dari bibir pantai di kedua kampung terdapat 8,1 Ha lahan yang masih belum termanfaatkan dengan baik (lokasi yang dulunya merupakan cottage taman bunga). Lahan ini seharusnya dapat dimanfaatkan menjadi lebih produktif jika dibandingkan dengan saat ini.

Penulis mempunyai sebuah pemecahan dari masalah yang ada di lokasi penelitian ini. Jika dihasilkan maka akan ada kemungkinan menggerakan sektorsektor ril yang devisanya langsung turun ke warga setempat. Lahan 8,1 Ha yang ada di sekitar bibir pantai lokasi tersebut sangat memungkinkan jika dibuat menjadi sebuah konsep pariwisata yang berwawasan ekologi dan edukatif yaitu Children Play Ground. Potensi fisik lokasi ini sangat mendukung, mulai dari iklim, morfologi, hidrologi semua memadai jika Children Play Ground ini dibangun di lahan ini. Sasaran dari konsep ini adalah orangtua beserta anak-anaknya mulai dari 
balita hingga remaja. Apalagi di sekitar lahan ini ada sebuah yayasan yang bergerak di Pendidikan Usia Dini, hal semacam ini dapat diberdayakan untuk menunjang potensi fisik yang ada. Kawasan ini sangat baik untuk konsep ini karena didukung dengan pemandangan yang cukup indah pula. Sebelah utara dihiasi dengan pemukiman warga yang sangat kampung dan sebelah selatan merupakan lautan Hindia yang diselimuti ombak besar yang indah.

Children Play Ground didirikan dengan tujuan memperkenalkan konsepkonsep ekologi dan lingkungan hidup yang tentunya sesuai dengan umur dari objek yang menjadi sasaran wisata ini yaitu anak-anak. Kawasan ini di desain untuk menjadi taman bermain yang memiliki fasilitas yang mendukung untuk anak-anak bermain, melakukan aktifitas lain dan bersosialisasi dengan pengunjung lain sekaligus mendapatkan pendidikan lingkungan hidup.

Children Play Ground akan dibagi menjadi tiga zona. Zona pertama merupakan Zona Local, zona ini merupakan zona dimana tempat bermain anak yang sangat kental dengan nuansa tradisional pedesaan. Anak-anak diarahkan untuk mengenal permainan-permainan yang ada di pedesaan, lalu mereka diperkenalkan kehidupan-kehidupan pedesaan yang sangat menarik bagi kehidupan orang-orang kota. Fasilitas yang ada di zona ini merupakan fasilitas bearoma pedesaan seperti, sawah, kerbau, kolam ikan dan permainan-permainan tradisional. Anak-anak.

Zona kedua adalah zona play on, yaitu terdiri dari fasilitas-fasilitas bermain anak yang bersifat have fun dan ketangkasan, seperti fasilitas bermain yang ada di taman kanak-kanak.

Zona ketiga adalah zona edukasi, di zona inilah anak-anak diberi pengetahuan mengenai lingkungan hidup dengan game-game atau fasilitas yang telah disediakan. Tidak hanya pengetahuan lingkungan hidup. Zona ini memberikan pengetahuan mengenai Indonesia dan bagaimana menjaga ekologi dengan simulasi-simulasi yang ada. Inilah konsep yang penulis berikan untuk menambah kaya ecotourism yang ada di Pelabuhan Ratu.

\section{- Zona Budaya Dengan Potensi Jelajah Kampung}

Sekitar tiga ratus meter dari pantai terdapat pemukiman penduduk dengan pola kehidupan desa yang masih alami, Kampung Bojongasih yang termasuk kedalam wilayah administrasi Desa Cikakak merupakan wilayah pedesaaan yang masih asri dengan nuansa desa yang masih kental. Penggunaan lahan di Kampung Bojongasih terdiri dari beberapa penggunaan lahan yang berbeda, yaitu lading, kolam air tawar, kebun, pemukiman, dan sawah. Dari pola penggunaan lahan yang ada sebenarnya terdapat daya tarik tersendiri jika dimanfaatkan menjadi salah satu komoditas ekowisata berbasis lingkungan dengan menggunakan kombinasi antar wisata budaya dan agro.

Dalam memanfaatkan segenap potensi yang ada maka bisa dimunculkan konsep yang dapat dijadikan salah satu komoditas ekowisata di daerah Desa Cikakak dan merupakan salah satu paket yang disediakan atau ditawarkan bersama dengan konsep children playground, yaitu sebuah konsep pengenalan lingkungan 
desa dan menikmati potensi hasil bumi desa dengan turun langsung ke lingkungan pedesaaan dan bekerjasama dengan penduduk desa tersebut. Konsep ini bisa disebut dengan nama jelajah Kampung Bojongasih.

Pelaksanaan konsep ini ditawarkan pada saat pengunjung memasuki kawasan children playground. Ketika anak-anak bermain di children playground, para orangtua akan ditawari paket jelajah kampong yang akan langsung dipandu oleh tour guide yang memang sengaja sudah disiapkan dari kalangan masyarakat sebagai salah satu upaya pemberdayaaan masyarakat.

Kegiatan pertama dilakukan dengan membawa wisatawan berjalan kaki menuju pemukiman penduduk yang bekerja sebagai pengumpul batu andesit dan basalt yang biasa dijadikan untuk tambahan hiasan dan ornament di tembok dan di taman, disana wisatawan akan mengenal salah satu mata pencaharian penduduk setempat sekaligus bisa belajar bagaimana proses pembuatan hiasan dari batu. Kegiatan kedua yang dapat dilakukan adalah belajar bercocok tanam di sawah bersama penduduk setempat yang memang sudah sengaja disiapkan sebagai salah satu bentuk kerjasama antara pengelola dan penduduk setempat. Kegiatan ketiga yang dapat dilakukan adalah memanfaatkan kolam air tawar masyarakat yang bisa diisi dengan kegiatan pemancingan ataupun menikmati bakar ikan sebagai mengisi waktu istirahat. Kegiatan kelima atau kegiatan penutup dari jelajah kampung adalah menikmati hasil kebun dari masyarakat setempat, banyak terdapat pohon buah-buahan seperti mangga, srikaya, sirsak, jambu air atau jambu bangkok, durian, belimbing dan lain-lain. pengunjung bisa membeli dan bisa mengambil langsung dari pohonnya, hal ini juga berguna untuk menumbuhkan perekonomian masyarakat.

- Zona Petualangan Dengan Potensi Air Terjun Cihaur

Potensi wisata alam menjadi komoditas utama ekowisata, untuk memanfaatkan potensi wisata yang ada di Desa Cikakak perlu dibuatnya ekowisata berbasis alam dengan objek utamanya air tejun cihaur yang memiliki ketinggian sekitar dua puluh meter yang terdiri dari dua air terjun. Potensi air terjun ini merupakan salah satu bentuk daya tarik wisata yang merupakan serangkaian dari petualangan kampung atau jelajah kampong.

Kondisi air terjun cihaur masih terawatt dengan keadaan yang masih alami, hal ini dapat terlihat dari sampah yang terdapat hanya sampah organic dari ranting atau daun yang jatuh. Akses menuju ke lokasi air terjun tergolong sulit karena wisatawan harus menurunu lembah dengan kemiringan lereng sekitar $60-70$ derajat.

Manajemen yang akan dilakukan pada setiap zonasinya adalah sebagai berikut: 


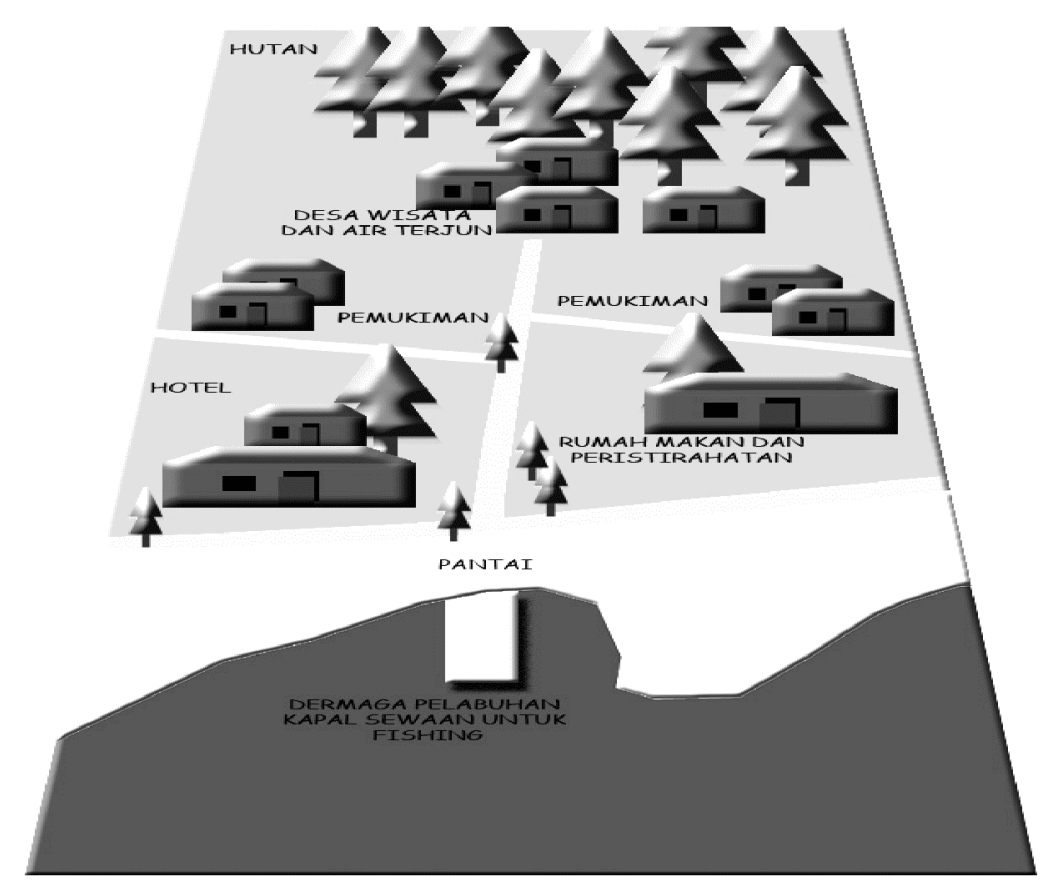

Gambar 3: Rewkomensdasi Desain Ekowisata di Kec. Cikakak dan Kec. Citepus.

Kapal-kapal sewaan untuk fishing dimana waktu yang di tawarkan untuk kegiatan ini adalah waktu-waktu banyak ikan yang biasanya terjadi setiap perubahan iklim, tapi tidak tergantung pada hal itu saja saat-saat biasapun bisa karena fishing ini cenderung mobail dan tidak terpaku pada satu wilayah saja.

Fishing ini potensial dijual pada para mancing mania dalam maupun luar negeri, dengan kualitas ikan plabuan ratu yang bisa di nadingkan dengan yang lain, dalam melakukan fishing ini masyarakat terlibat langsung sebagai pemandu dengan pelatihan-pelatihan kepemanduan sebelumnya, alasan masyarakan yang menjadi pemandu adalah masyarakat setempat telah mengetahui lokasi-lokasi penangkapan ikan yang bagus juga telah mengetahui kondisi daerahnya sendiri baik dam buruknya. Walau semua kegiatan ini harus ditopang oleh teknologi pengamanan dan pendeteksian lokasi ikan yang canggih, tapi tetap peran turguid dari masayakat setempat sangatlah berarti. Untuk pengamanan wisatawan bisa menggunakan pelampung, sekoci darurat, radio, dan gps.

Untuk mendukung keberadaan zonasi pantai maka dibuat sebuah hotel, peristirahatan, dan rumah makan di zonasi 2 . Dengan melihat pada penggunaan lahan di zonasi 2 atau zonasi agro yang banyak didominasi oleh pertanian padi, maka sangatlah nyaman jika setelah lelah berkeliling pantai untuk memancing kemudian singgah di peristirahatan untuk sekedar membakar atau memasak ikan yang telah ditangkap sambil melihat padi dengan tiupan angin sepoi yang langsung menerpa wajah, pasti rasa lelah yang barusaja di alami setelah kegiatan memancing tadi, perlahan-lahan akan hilang sambil mencicipi hidangan ikan hasil tangkapan 
sendiri dengan ditemani makanan lainnya yang sudah di siapkan oleh pihak rumah makan.

Pada zona 2 ini atau zona agro pengelola lebih cenderung menjual suasana, dimana pengelola memberikan suasana yang nyaman, sejuk, dan asri yang secara sendirinya dapat menghilangkan stres yang dialami oleh pengunjung. Waktu yang disediakan untuk wisata ini fleksibel tergantung banyaknya pengunjung yang datang, jika perlu sampai lembur. Di lokasi ini segmen pasar yang utama adalah para mancing mania yang barusaja selesai memancing tadi, tapi tidak terfokus hanya pada itu saja, wisatawan lain pun yang datang kepelabuan ratu untuk mendapatkan suasana tadi pun adalah segemen pasar bagi ekowisata ini.

Bagi orang-orang yang gemar akan petualangan, di zonasi 3 atau zonasi petualangan kami menyediakan lokasi wisata yang berbasis petualangan. Petualangan yanng kami adakan di lokasi ini diantaranya outbond, air terjun, dan desa wisata sebagai pelengkap ekowisata yaang terdapat di wilayah 2 . Pengamanan pada kegiatan petualangan ini sangatlah diperhatikan seperti firs aid, penjaga hutan, tourguid, dan lain-lain yang dibutuhkan dalam pengamanan. Segmen pasar pada zona ini adalah orang-orang yang senang memacu adrenalin atau orang orang yang sengaja melangcong untuk mendapatkan pengalaman barui baik itu dari dalam maupun luar negeri.

- Desain mitigasi bencana dalam pengembangan daerah ecotourism

Dalam pengembangan wisata dalam hal ini ecotourism, maka faktor-faktor keselamatan jiwa baik para wisatawan maupun masyarakat lokal yang terkait dalam ecotourism harus diperhatikan, keselamatan tersebut meliputi keselamatan kerja atau keselamatan baik agar terhindar dari bencana alam. Potensi kebencanaan pastilah ada apalagi daerah ecotourism ini berbatasan langsung dengan Samudera Hindia yang umumnya berpotensi terkena dampak terjadinya tsunami. Maka dari itu pengembangan ecotourism juga harus memperhatikan kemungkinankemungkinan yang bias terjadi karena bencana sangat sulit atau bahkan tidak bias diprediksi. Untuk mengantisipasi hal tersebut, maka dibuatlah jalan-jalan penghubung yang sifatnya memotong arah pantai menuju dataran yang lebih tinggi atau dalam hal ini perbukitan. Beruntung kawasan ecotourism ini memiliki relief dataran pantai dan pesisir pantai yang curam, dataran yang tergolong rendah hanya berjarak sekitar 200-500 meter dari pantai, sehingga untuk evakuasi jika sewaktuwaktu terjadinya tsunami bisa lebih cepat dan efektif dengan dibuatnya jalan-jalan yang dijadikan jalur utama ataupun jalur alternative dalam mitigasi bencana.

\section{Penutup}

Pengelolaan ekowisata di kawasan Palabuhan Ratu khususnya di wilayah kecamatan Cikakak dapat di dibagi menjadi 3 jenis desain pengelolaan. Jika dilihat dari desain tersebut maka lokasi tersebut yang terdiri dari zona 1,2, dan 3. Dimana dari 3 desain tersebut dibuat semacam bentuk wisata yang saling berkaitan satu dan lainnya. Dimana zonal yaitu aktivitas berbasis pantai akan didukung oleh zona 2 
atau aktivitas berbasis agro dan zona 1 dan 2 akan didukung oleh zona 3 atau zona berbasis aktivitas petualangan.

Rekomendasi atas dasar pertimbangan di atas sebagai berikut :

1) Menata tata ruang dan wilayah yang berkaitan dengan aspek pola pemukiman, letak geografis, iklim, tanah, topografi, air,

2) Penerapan Konsep wisata harus dilakukan dengan memerlukan analisis analis yang dilakukan oleh pemerintah daerah untuk menentukan potensi yang ada di daerah Desa Cikakak dan Citepus.

3) Harus diadakannya pembenahan fasilitas fasilitas umum untuk menunjang kenyamanan dan keamanan wisatawan yang berkunjung ke daerah tersebut.

4) Diperlukannya investasi dari para investor untuk menanamkan modalnya untuk menunjang keberlangsungan wisata yang dikelola baik fasilitas maupun sumberdaya manusia.

5) Dalam penerapan wisata harus memperhatikan isu dan aspek lingkungan yang nantinya akan menjadi sorotan tajam secara nasional dan internasional, jika isu ini dapat dikelola dengan baik, maka akan menjadi "strenght point" terhadap nilai jual dari obyek dan atraksi wisata yang ada di Cikakak.

6) Untuk menghindari benturan yang akan terjadi pada masa datang yang berakibat pada kerugian semua pihak, maka penerapan wisata perdesaan ini harus memperhatikan nilai-nilai yang ada dan tumbuh di tengah-tengah masyarakat, khususnya masyarakat setempat, yang dapat merusak budaya mereka serta nilai-nilai agama yang dianut.

\section{Daftar Pustaka}

Bappeda Pemkab. Sukabumi. 2007. Rencana Induk Pengembangan Pariwisata Daerah (RIPPDA) Kabupaten Sukabumi.

Damanik, J. \& Weber, H.F. 2006. Perencanaan Ekowisata. ANDI: Yogyakarta.

M. Nur, Djakaria. 2008. Otonomi Daerah Dalam Pengembangan Sektor

Pariwisata, Jurnal Geografi. Jurusan Pendidikan Geografi-FPIPS UPI.

Suwantoro, Gamal. 2004. Dasar-dasar Pariwisata. ANDI. Yogyakarta

Tribuwani, Wiwien. 2001. Sekali Lagi, Pariwisata Alam, Pariwisata Berkelanjutan

Dan Ecotourism. Pusat Kepariwisataan - ITB.

http://www.unepie.org/tourism/library/ecotourism.htm

http://www.ekowisata.inf

http://www.wisatamelayu.com

http://www. ekowisata.info 